\title{
An (other) 'story' in history: Challenging colonialist public relations in novels of resistance
}

\section{Introduction}

Critical public relations (CPR), as the recent Routledge Handbook of Critical Public Relations (L'Etang, McKie, Snow, \& Xifra, 2016) comprehensively demonstrates, is beginning to provide a broader vision of public relations which not only looks at the interests and aspirations of a variety of publics beyond corporate ones but also challenges limiting mechanistic and propagandist approaches to understanding public relations. Alongside this broader vision is a growing acknowledgement that the history of public relations goes a long way back before the term public relations began to be used (Lamme \& Russell, 2010; Watson, 2015). Building on Russell and Lamme's (2016) theorizing of public relations history based on "strategic intent and human agency" across place or time, we further expand the discursive space of public relations by tracking insights in works of fiction. These insights give us an opportunity to not only critically examine the overt as well as covert public relations strategies used by colonial powers to assert their political and cultural superiority but also to show how colonized peoples used their own forms of public relations to resist colonialist practices and rally subaltern publics together.

Exploring fiction opens up a fresh window into history and provides an opportunity to reassess as well as critique mainstream versions of history (De Groot, 2016). In his wideranging tome on Remaking History, De Groot (2016) shows how “(F)ictions challenge, 'pervert', critique, and queer a normative, straightforward, linear, self-proscribing history" (p.2) and suggests that they come up with innovative models of understanding the past.

There is indeed a symbiotic relationship between history and historical fiction. Both are representations of facts and events and open to interpretations. If historical fiction is a 
particular take on real-life characters or a particular imagination of events that unfolded in the past, so is history. As the historian Hayden White (1973) says history is not some neutral record of the past. Historical work, as he points out, comprises five elements: “(1) chronicle; (2) story; (3) mode of emplotment; (4) mode of argument; (5) mode of ideological implication" (White, 1974, p. 5). The meaning of history, as in a fictional story, depends on what White (1973) calls "emplotment" or the "way by which a sequence of events fashioned into a story is gradually revealed to be a story of a particular kind" (p. 5). In other words, a history of an epoch or an event is a narrative that is as much informational as it is ideological. The influence of a particular narrative inevitably relies on the power wielded by the narrator. Postcolonial scholars such as Edward Said (1978), Anne McClintock (1995), and Dipesh Chakrabarty (2000), to name a few, have exposed the ways in which Western literature and art of colonial times systematically composed a narrative that deliberately constructed an inferiorized 'other' to reinforce the authority of dominant elites. Such processes of 'otherization' have continued into the contemporary era of globalization with overt and covert forms of cultural imperialism (Cao, 2007). Indeed, these processes of domination by elite institutions from powerful governments to large corporations have been aided by mainstream public relations (Munshi \& Kurian, 2005; 2007; Dutta \& Pal, 2011). At the same time, however, PR has also been effectively deployed 'as a tool of resistance' in 'alternative histories of communicative action that remain largely un-documented' in the traditional public relations literature (Munshi \& Kurian, 2016, p. 407).

In recasting ways of looking at the history, politics, and anthropology of public relations, we argue for a radically different kind of lens through which to explore the field -one that goes beyond colonialist interpretations of 'facts and figures' stored in state archives, which inevitably reflect dominant ideologies of those who wrote them in the first place. We draw on a framework of historiography first constructed by scholars of the Subaltern Studies 
Group, led by Ranajit Guha (1982) and his fellow South Asian historians and political scientists such as Shahid Amin (1995), Dipesh Chakrabarty (2007), and Gyan Prakash (1994), which challenge elitist histories and bring out alternative versions of histories through the voices of those who have been subjugated by political power.

In this endeavour, we build on recent work in CPR (e.g., Munshi \& Kurian, 2016; Heath \& Xifra, 2016; McKie \& Xifra, 2016) and move away from the age-old obsession of mainstream public relations with “dominant coalitions” (Broom \& Dozier, 1996; Grunig, 1992; Grunig \& Hunt, 1984). As critical scholars have pointed out, the emphasis on recording and disseminating messages constructed by dominant organizational publics has limited the scope of public relations to a narrow form of corporate communication. As a result, public relations has often come to be seen to "represent the neo-colonial agenda of Western marketbased lobby groups" (Munshi \& Kurian, 2016, p.406), leaving those outside neo-liberal power structures such as immigrant workers, refugees, indigenous communities, citizens of war-torn states, and other vulnerable peoples, with no access to the discursive space of public relations (Dutta \& Pal, 2010). With hardly any recording of the voices of the marginalized in the history of public relations, we turn to historical novels as a resource for exploration.

\section{Methodology}

The counter-narratives offered by protagonists of historical novels provides rare insights into public relations that serve to bring into crisis elite, homogenous discourses on nation, culture and colonialism that continue to have currency. These narratives give us a chance to reflect on the subaltern challenges to the dominant voices that have historically sought to invisibilize and wipe out alternative understandings of the implications of colonialism. Such reflections, in turn, become one way to respond to the call for "a global theory of public relations by taking into account the native's point of view (Sriramesh, 2009, 51 ; italics in the original). While we do not advocate replacing one metanarrative with 
another, there is an urgent imperative to open up public relations to the voices of multiple publics, especially those whose voices have rarely been heard, and to do so through drawing on a multiplicity of sources.

If the discipline of modern history is recognised as "an instrument of European nationalism" and "a tool of nationalist ideology" (Geary, 2003, p. 15), then the task of postcolonial scholarship is to diversify that enterprise by excavating alternative interpretations and understandings of the past that help construct alternative realities. The emerging discipline of critical management studies (CMS), which has significantly drawn on postcolonial approaches, has already made some deep explorations into the "contestation about knowledge" produced in different versions of history (Prasad, Prasad, Mills, \& Mills, 2016, p. 4). In a thoughtful chapter on "Debating Knowledge”, Prasad et al (2016) investigate, for example, on why a very positive Central Asian history of Mughal India in the $17^{\text {th }}$ century is so different from the overwhelmingly negative account of the same by Sir Thomas Roe, the English ambassador and chronicler for King James I. The power-play involved in interpreting knowledge, the authors say, is increasingly central in the rapidly-changing contemporary world and the scholarly field of CMS "needs to be a full-scale participant" in the debates around contested knowledge (p. 4). So does CPR and this paper is an attempt to critically reinterpret PR though historical narratives.

Critical methodology, as CMS scholars Alvesson and Ashcraft (2011) point out, "tends to call into question established social orders - dominating practices, discourses, ideologies, and institutions" and "contribute to the disruption of ongoing social reality for the sake of rousing resistance to relations of constraint and domination" (p. 61). At a methodological level, we are able to critically interrogate widely accepted understandings of public relations quite simply by choosing a different set of sources. Rather than look at mainstream historical accounts of business and commercial enterprise, we identify a body of 
historical fiction to explore another history of public relations. As Doran (2013) says about the work of White (1973), "history is as much a product of the imagination as it is of the 'facts"” (p. 109) and "tells us as much about the producers and consumers" of such history "as it does about its ostensible object" (p. 115).

In this article, we specifically explore historical fiction by contemporary novelists who provide another set of stories involving ordinary characters to challenge colonialist narratives and construct alternative histories. After a search for narratives from diverse regions of the globe, we decided to focus on three sets of writers and their works: (1) Amitav Ghosh's $(2008 ; 2011 ; 2015)$ fascinating rendition of subaltern histories of British imperialist forays into India and China; (2) Chimamanda Ngozi Adichie's (2004; 2006; 2009) passionate expose of what she calls "the danger of a single story"; and (3) Spanish journalist and novelist José-Luis Pérez-Regueira's (2014) best-seller Una cruz de jade para Cortés (A Cross of Jade to Cortés) which provides an alternative to the official history of the colonization of México. These three novels cover the geographical breadth of colonized worlds and are authored by writers with a deep sense of history and academic training.

Despite the differences in local (and historical) contexts, styles, and the intellectual reservoirs of knowledge they dip into, there is something strikingly similar about these contemporary historical novelists. In looking at the past, they not only unearth other versions of history but they also provide a sharp commentary on the political economy of the present day that drives contemporary PR initiatives. The strategies used by today's political elitecorporate nexus to justify wars and inequitable public policies in the interests of global economic agendas and rampant development are not much different from the ones used by colonial empires of the past. Similarly, in both cases, there has been an active resistance to the dominant forces of power. But these contemporary novelists do not simply draw parallels between the past and the present nor do they etch the interactions between the colonizers and 
the colonized in black and white terms. They point to the sophisticated ways in which the idea of 'empire' is enacted. There are no real boundaries of nation, race, and class with categories expanding and collapsing in the ebb and flow of communicative tides - in essence, the strategic use of communication holds the balance of power in specific contexts. There are no boundaries between the local and the global either or, for that matter, between fact and fiction. The stories of everyday characters weave seamlessly into constructing alternative histories of familiar and unfamiliar pasts.

In following the "narrative turn" in organizational research (see e.g., Czarniawska, 2004; Fenton and Langley, 2011; Keulen and Kroeze, 2012; Rowlinson et al., 2010), we use the fictional narratives of the three novels as the units of our narrative analysis. As Rhodes and Pullen (2011) say, "researchers have turned to narratives from literature and various forms of popular culture as exemplars of knowledge about organizations and management" because there is an increasing awareness that "there are others outside of academic research who are much more practiced and skilled at telling stories about work and organizations" (p. 594). This is an approach that can be productively used in the area of public relations as well. To begin our exploration of the work of our chosen novelists, we first turn to the Ibis trilogy, the three-part magnum opus of the South Asian writer, Amitav Ghosh.

\section{Drugs, drumbeats, and the dazzle of colonial spin}

The three novels that comprise Ghosh's trilogy - Sea of Poppies (2008), River of Smoke (2011), and Flood of Fire (2015) - document the intricate, and often manipulative, communication strategies used by the British Empire to establish colonial political, military, and business supremacy in Asia as well as the everyday resistance of ordinary characters who formed their own coalitions against British dominance. The march of the British Empire into India was rhetorically positioned as a 'civilizing mission' to educate the masses, to introduce 
the rule of law to the seemingly anarchic domains spread across a vast land, and to bring individual liberties to oppressed people. In the British governor general Lord Curzon's (1905) words - akin to a modern-day public relations "mission statement" for the Empire - the purpose of going into India was to

fight for the right, to abhor the imperfect, the unjust or the mean ... and to feel that somewhere among these millions you have left a little justice or happiness or prosperity, a sense of manliness or moral dignity, a spring of patriotism, a dawn of intellectual enlightenment, or a stirring of duty, where it did not before exist. (pp. 589590)

Yet, under the surface of this so-called civilizing mission was a heady mix of greed, deceit, and an unabashed lust for economic and political power. Having entered the country as a commercial trading entity - the East India Company - the British soon took possession of India by striking deals with select rulers of princely states and invading others, destroying long-lasting agrarian structures, enlisting local people into its vast army, and dividing the local populations by institutionalizing and cementing divisions along religious, caste, and regional lines. As the captain of the schooner Ibis, in the first of Amitav Ghosh's trilogy, Sea of Poppies, tells his subordinates, "The day the natives lose faith in us, as the guarantors of the order of castes - that will be the day gentlemen, that will doom our rule" (p. 442). Yet, as historians of the British Empire have made clear, it was the introduction of censuses in India by the British that led to formal organization and rigid stratification of society by caste. These records formed not only the basis of British ideological understandings of and administrative practices in India that were deeply imbued by racism, but also the transformation of Indian society as Indians adapted themselves to the new hierarchies to advance their material status in society (see Hobson, 2010; Bandyopadhyay, 1990). As Ghosh points out, "In fact, the 
British did everything they could to reinforce the hierarchical aspects of Indian society - and indeed they introduced hierarchies of their own" (Ghosh \& Chakrabarty, 2002, p. 158). Colonial practices and policies on caste continue to form the basis of the on-going castebased conflicts and violence that can be seen in India today.

The British prided themselves in bringing the rule of law to India; yet it was clear from the beginning that there was no question of allowing any legal statute to come between the British and their commercial interests, leading to actions that rationalized, for example, the illegal appropriation of coveted land and wealth of the locals. Indeed, as Neel Rattan Halder, one of the characters in the Sea of Poppies, reflects, the British themselves had taken on the role of upper castes despite professing the values of equality:

It had become almost laughably obvious to Neel that in the system of justice it was the English themselves - Mr Burnham [an English businessman] and his ilk - who were exempt from the law as it applied to others: it was they who had become the world's new Brahmins. (Ghosh, 2008, p. 221)

As Ghosh (2002) comments in another context, Thus, in British India, "the rule of law" is actually "the rule of law + R[ace]"... Built into this institution were the grounds for its own future subversion for it was founded on an implicit understanding that the rulers were, if not quite above the law, then certainly subject to a different species of law than that which applied to the ruled (p. 148).

Ghosh's trilogy vividly brings to light numerous instances of such arbitrary violations and subversions of the law, all couched in explicit or implicit racist justifications. 
Among the many threads of the British duplicitousness that wove together the fabric of British colonialism, Ghosh looks most specifically at two. One is the commercialization of forcibly impoverished rural Indians by carrying them as indentured labour to other colonies and luring them to join military expeditions not only against their own country folk but also against foreign countries with which India had no enmity. The other is the intricate web of a lucrative trade in opium which involved the extensive cultivation of poppy crops in India at the expense of food crops and forcing the drug down the throats of the Chinese despite China's steadfast opposition.

Alongside the Ibis which carries indentured labour to the isles of Mauritius are two other ships Anahita and the Redruth which provide central locales in the course of the trilogy that moves likes the waves of an ocean from the Sea of Poppies to River of Smoke and finally to Flood of Fire. The complexities of commerce, society, and politics emerge through the network of relationships among the huge range of characters including British military commanders, royal officials, traders, botanists, and gentlemen and women; Indian soldiers, sailors, peasants, learned but ineffectual landlords, clerks, Anglicized business people; and Chinese officials, boat people, and agents; as well as people who have multiple identities. It is in the intricate ebb and flow of communication within the matrices of relationships that we see the layers of public relations play out. The English spout the glories of progress and democracy to justify their every move to reinforce their economic supremacy. This is most evident when, in the name of free trade, British merchants, supported by the royal navy, sell opium to a seduced Chinese population and resort to war when the emperor of China opposes them. We see the easy slippage between Enlightenment values of liberty and freedom, capitalist economic principles of free trade, and an evangelical religious discourse of salvation in the following quotes: 
The war, when it comes, will not be for opium. It will be for a principle: for freedom - for the freedom of trade and for the freedom of the Chinese people. Free Trade is a right conferred on Man by God, and its principles apply as much to opium as to any other article of trade. More so perhaps, since in its absence many millions of natives would be denied the lasting advantage of British influence. (Benjamin Burnham, opium trader and businessman, in Sea of Poppies (Ghosh, 2008 p. 106)

Neel: "Does it not trouble you, Mr Burnham, to invoke God in the service of opium?" "Not in the slightest," said Mr Burnham... "One of my countrymen has put the matter very simply: "Jesus Christ is Free Trade and Free Trade is Jesus Christ." (Dialogue in Sea of Poppies, (Ghosh, 2008, p. 106)

But, in parallel, there is a less noticeable, but active, communicative alliance in resistance as well. The vibrant, riotous landscape and seascape of the novels brim with the lives, relationships, passions and perspectives of the many who have remained in the margins of mainstream histories. They include Deeti, a peasant woman who escapes immolation on a funeral pyre and arrives as part of an indentured labour force in Mauritius, Zachary Reid, a mulatto freedman, Kesri Singh, a sepoy in the East India Company army, opium traders, sailors, and others. Ghosh (2008) depicts the creation of transformative alliances and relationships emerging amongst the indentured labourers travelling to Mauritius: "Yes, said Deeti, from now on, there are no differences between us; we are jahaz-bhai [ship brothers] and jahaz-bahen [ship sisters] to each other; all of us children of the ship" ( p. 328; translation in parenthesis added). Elsewhere, we see how sailors and tradespeople from Bengal and Bombay join hands with Dan boat people and Hakka merchants of China to create an alternative nexus that resists the overwhelming military might of the British. In a particularly 
moving scene, Kesri, a mercenary Indian soldier fighting the British war in the faraway land of China, realises the folly of having succumbed to the lure of British money when he watches the bravery of a Chinese soldier who dies defending his motherland. When Kesri sees the expression on the dying man's face,

he knew it to be the look that appears on men's faces when they fight for their land, their homes, their families, their customs, everything they hold dear. Seeing that expression again now, it struck Kesri that in a lifetime of soldiering he had never known what it was to fight in that way ... for something that was your own, something that tied you to your fathers and mothers and those who had gone before them, back into the dimness of time. (Ghosh, 2015, p. 472)

The dominant narratives of the colonial era are not much different from the ones of today. Substitute opium of the $19^{\text {th }}$ century with oil of the $20^{\text {th }}$ and, arguably, water of the $21^{\text {st }}$ and the propagandist features of dominant communication messages of then and now seem strikingly similar. For example, "for the war in Iraq, the U.S. government engaged in public relations activities but also in all forms of propaganda - white, black, and gray" (Hiebert, 2003, p. 244). The propaganda blitz by the governments of George Bush in the U.S as well as Tony Blair in the U.K. at that time included planned strategies such as dressing up misinformation, staging media relations, using celebrity briefers, embedding journalists in frontline operations, orchestrating visuals, and presenting the war as a spectacle (Hiebert, 2003). Similarly, Kellner (2007) argues that the "Bush administration, aided and abetted by the U.S. corporate media, manipulated a politics of fear to push through a right-wing agenda that included the Patriot Act, massive changes in the legal system, a dramatic expansion of the U.S. military, and U.S.-led military intervention in Afghanistan and Iraq" (p. 622). The public relations campaigns of Bush and Blair to justify the war on Iraq and Afghanistan in the 
name of democracy and "freedom" were to a large extent the continuation of colonial-era strategies to mask the addictive craving for economic and political gains by dominant states hand in glove with big business enterprises.

\section{Colonial rhetoric of war, race, and division}

While Ghosh traces the historical trajectory of the Opium war inflicted on the Chinese, run directly by British commanders with the help of mercenary Indian soldiers, Chimamanda Ngozi Adichie paints a graphic picture of the Biafran War in Nigeria, a legacy of British colonialism in Africa. The Biafran war in the late 1960s is popularly documented as the Nigerian civil war between the Hausa tribes of the North, the majority community of Nigeria, and the Igbos of the East who had broken away from the newly-independent Nigeria to form a breakaway republic of Biafra. But what is less known is the role of the British in a covert state-sponsored suppression of the Igbos since 1945 when members of this community launched a strike to demand independence from colonial rule. As Herbert Ekwe-Ekwe (2013) documents, the colonial regime's “inflammatory propaganda on 'Igbo responsibility' for the event" instigated massacres of Igbo immigrants in the northern city of Jos that year. This was followed by a similar pogrom in another northern town, Kano, in 1953, after the Igbos supported a timetable for the end of British occupation. Even after Nigeria's independence, the British and their US allies opposed the Igbos' move to break away and form a state of Biafra, leading to an utterly preventable civil war that claimed millions of lives. Ekwe-Ekwe (2013) cites Roger Morris (1977) to claim that the then British Prime Minister communicated to the US that he "would 'accept a half million dead Biafrans if that was what it took' Nigeria to destroy the Igbo resistance".

It is against this backdrop that Adichie's powerful novel Half of a Yellow Sun is set. One of the characters in the novel is Richard Churchill, an Englishman who arrives in eastern 
Nigeria to study Igbo-Ukwu art, falls in love with a local girl, and is drawn to Biafran politics. In an article he writes on the unfolding war, he provides the political context for the war:

It is imperative to remember that the first time the Igbo people were massacred, albeit on a much smaller scale than what has recently occurred, was in 1945. That carnage was precipitated by the British colonial government when it blamed the Igbo people for the national strike, banned Igbo-published newspapers, and generally encouraged anti-Igbo sentiment. (Adichie, 2006, p. 166)

The British public relations rhetoric in the world of global diplomacy focused on the political sanctity and territorial integrity of newly independent states. On the face of it, the British didn't want Nigeria disintegrating and so opposed the breaking away of Biafra. But, as in colonial as well as contemporary neo-colonial times, control over economic resources and political power was the hidden subtext. Reacting to a police action against the rebels, Richard's girlfriend in the novel, Kainene says: "It's the oil ... They can't let us go easily with all that oil." In fact, in an interview post-Half of a Yellow Sun, Adichie is quite clear that if the original boundaries of Biafra had not included the Niger delta with all the oil, Biafra would have been an independent country today. I don't doubt that. It was the oil, the reason they said you can't go and was the reason behind Britain's concerted support (for Nigeria) and oil really was behind the war. (Birnbaum, 2006).

The malignant influence of British public relations was such that the Nigerian elite who took the reins of power after independence followed the same style of governance, seeking to emulate the colonial model that would allow them to corner the wealth of the nation for themselves. In a separate interview, Adichie says that colonialism "created conditions where the Africans who took over became colonialists themselves. They were copying what they had seen" (Kimber, 2006). Class divisions became far more entrenched as is evident in the novel's intense critique of social mores in which money was the supreme 
driver. A striking example is in the way of one of the principal characters, a young woman, Olanna, is offered to strangers in exchange for business deals.

Of course, as in the world of Ghosh, the narratives of Adichie are not binaries. It's not a simple plot of colonial evil versus native good. In both cases, the relationships are complex and just as there are oppressive locals, there are European settlers who are part of the resistance against colonialism. Race and ethnicity are, of course, an integral part of the web of relationships. But, what holds the balance of power in the relationships is the interplay between the discourses of public relations. For example, the justification by British governors of the need for a particular constitutional framework of an independent Nigeria reflected the communicative power deployed to actually reinforce the power of one tribal group, that of the majority Hausa-Fulani, over another. Adichie says that the British helped the first government of independent Nigeria to ascend "to power: through fraud and on the basis of a constitution that favoured" a particular community (Kimber, 2006). This arrangement allowed the British to retain proxy control over Nigeria. Such a divide and rule strategy was evident in colonial India as well where the British played one princely state against another as well as Hindus against Muslims to maintain their dominance.

Interestingly, it is the insidious power of colonial public relations that mesmerises ordinary Nigerians to believe in the superiority of Western ways of living. Adichie's most recent novel Americanah charts the stories of Ifemelu and Obinze, two teenagers who grow up with a starry-eyed view of the West shaped by the literature of popular novelists such as James Baldwin, Graham Greene, and Mark Twain. Ifemelu is drawn to the US for her postgraduate studies while Obinze moves to England, playing hide and seek with the bureaucracy to get a legal status for work. Both confront a very different world and are instantly sucked into an intricate web of identity struggles involving race, ethnicity, gender, nation, and belonging. Their experiences demonstrate how public relations is "complicit in 
the privileging of whiteness that is implicit in the way issues are framed" and how "racialized elites and non-elites are created as social groups by PR processes" (Munshi \& Edwards, 2011). In exploring race as a communicative process rather than a biological construct, Munshi and Edwards (2011) show how Whiteness is "a visible and systemic form of race as process" that interacts with non-White forms, a process in which elites are not always white just as non-elites can include white communities. Public relations has historically privileged white norms and white ways of living (Edwards, 2010), norms that have now become synonymous with elitism. In Americanah, for instance, Ifemelu confronts race in the US as a non-white international student but is indignant at being perpetually bracketed with the Blacks of the country. She writes an incisive blog called Raceteenth or Various Observations About American Blacks (Those Formerly Known as Negroes) by a Non-American Black, which is severely critical of the benchmarking of whiteness as the norm; for example, she notes how up-market beauty salons don't have time for kinky hair or how non-whites are clubbed together into an amorphous group of the "other". In one post, she writes:

Dear Non-American Black, when you make the choice to come to America, you become black. Stop arguing. Stop saying I'm Jamaican or I'm Ghanaian. America doesn't care. So what if you weren't 'black' in your country? You're in America now. We all have our moments of initiation into the Society of Former Negroes. (Adichie, 2013, p. 220)

But, as Ifemelu says in another of her blogs, the clubbing together of minorities does not necessarily unite them. The colonial era discourse of divide and rule rears its head in a more sophisticated form:

Oppression Olympics is what smart liberal Americans say to make you feel stupid and to make you shut up. But there IS an oppression olympics going on. American racial minorities - blacks, Hispanics, Asians and Jews - all get shit from white folks, 
different kinds of shit but shit still. Each secretly believes that it gets the worst shit. So, no, there is no United League of the Oppressed. However, all the others think they're better than blacks because, well, they're not black. (Adichie, 2013, p. 205)

The politics of divide and rule, as discussed earlier, was an essential strategic communication device in colonial times. This framework continues to be used by dominant coalitions in contemporary times as can be seen on the global climate policy making arena, where wealthy nations' refusal to take responsibility for creating the problem is translated into blaming developing nations, such as China and India, for their 'survival emissions' (Agarwal \& Narain, 1992), and splitting the ranks of third world states'seeking accountability from the first world. It is also seen in the work of exploitative corporations, for example, using expensive campaigns to render invisible the oil spills, destruction of habitats and economic systems of survival that harm indigenous peoples and peasant communities while the foreign exchange they provide national governments keep the elites happy.

\section{Colonial conquests, indigenous alliances, and the power of translations}

The language used by colonial powers in their public relations initiatives is often assumed to be the language of the colonizers - be it English, Dutch, Portuguese, Spanish or any other - but what remains underemphasized is the tactical use of key translators in colonial conquests. José-Luis Perez-Regueira's (2014) bestselling novel, Una cruz de jade para Cortés (A cross of jade to Cortés) chronicles the Spanish conquest of Mexico by highlighting the role of a woman translator and strategic communicator who was strikingly ahead of her time. Mexico was the cradle of several outstanding civilizations (the Olmec, the Maya, the Toltec, the Mixtec, the Zapotec, and the Aztec among others) before European colonization. Military might, of course played a major part in the Spanish incursion into 
Mexico in the early 1500s but the Europeans could not have made the deep inroads they did without help from within.

An unlikely ally for the colonizers was an indigenous woman called Malintzin, whose Nahuatl name was changed to the mestizo-sounding Malinche, and eventually to Christian Doña Marina after her baptism. In many ways, her different names tell the story of her own life: a woman who did not fully belong to any specific group, her otherness setting her apart at every stage (Crhová \& Escandón, 2011). Malinche, the Mayan translator for the Spanish Conquistador Hernán Cortés, came to be known as one of the most condemned figures in Chicano culture, primarily for what was seen as her betrayal of the Mexican people. Although she is an historical figure, historians know little about the details of Malinche's life. As a young woman, Malinche, along with 20 other women, was given as a gift to Cortés' expedition after their victory over the Mayan town of Potonchan (Fehrenbach, 1973; Miralles, 2001). Cortés passed her on to one of his men, Hernández Puertocarrero, who spent some time with Malinche before leaving for Europe never to return (Bennassar, 2001; Miralles, 2001). Although her childhood and original tribal affiliation are subject to speculation, it is known that she spoke two native languages, Mayan and Nahuatl, and later learned Castilian Spanish, a skill that eventually led Cortés to take her into his inner circle and give her the role of translator. Malinche not only led the negotiations between the Aztec city of Tenochtitlan and the Spanish conquistadors but was also Cortés' lover and the mother of his child, Martín Cortés, who is commonly accepted as the first mestizo (person of both Mexican and European blood) (Candelaria, 1980).

Portrayed as a near-mythical character, Malinche has captured the imagination of several writers. Octavio Paz (1993), for example, presents her as a raped, passive woman (whom he calls La Chingada) who gives birth to a malformed child. In a metaphorical sense, she 
became an allegory of women, gazed at, raped or seduced by Spaniards. Paz (1993) shows Doña Marina as surrendering herself to Cortés of her own volition although historians claim that she had been sold by her own mother and stepfather to some merchants before being eventually offered along with 19 female slaves as a present to Cortés upon his arrival at Tabasco (Crhová \& Escandón, 2011).

Other portrayals of Malinche range from Cordelia Candelaria's (1980) depiction of her as a feminist prototype and Pratt's (1993) description of her as a mythic figure to Meza's (1985) sketch of her as a victim. What is less highlighted is Malinche's public relations role in helping Cortés to forge alliances, to conduct negotiations, and even to wage war. As Martínez San Miguel (2008) argues, we cannot think of Malinche as a victim without taking into account that she was involved in dealings with the same men who annihilated so many Amerindians and destroyed civilizations. Furthermore, it is noteworthy that Malinche enjoyed a high status as proven by Indian oral accounts and codices (Brotherson, 2001). Similarly, Malinche was seen as a somewhat free agent and in control of the discourse involved in the exchanges that took place between the colonizers and the tribal groups (Baudot, 2001). Going by Díaz del Castillo’s (1956) historical account, Malinche was an adroit speaker who handled thorny situations successfully: "Doña Marina helped the Spaniards in the war in Tlaxcala, Tenochtitlán and the New Spain” (1956, p. 39).

Perez-Regueira's novel provides a rare perspective on into Malinche. She is a very different character from the ones usually presented in the colonial landscape. Unlike the freedom-fighters who resist colonial rule, Malinche's resistance comes through in wholly new ways. By collaborating with the colonizers, she actually fights for the legacy of her ancestors. In the novel, Malinche is an advocate of the freedom of the tribes she comes from - the Totonacs, the Talaxcaltecs, the Otomi people and other indigenous ethnic groups - who 
were crushed under Aztec domination. She joins hands with Cortés to forge alliances with a number of indigenous groups facing Moctezuma's Aztecs. She may even have been one of the first spin doctors in history, given her skillful deployment of strategic communication for political purposes. Indeed Una cruz de jade para Cortés (2014) is not just a historical review of the Spanish conquest of Mexico; it is a review that provides an incisive look at the resistive communication strategies of a little-known practitioner. The novel shows how an episode of Spanish colonization was also an opportunity of resistance for pre-Columbian peoples oppressed by the Aztec empire led by Moctezuma. Pérez-Regueira's heroine is a skillful communicator with a powerful weapon: the ability to learn different languages and translate from one to the other. At one point, Malinche who learns of an Aztec plan to corner the Spanish Army alerts Cortés to the danger and even as she pretends to cooperate with her informants, she creates the ground for Cortés to turn the tables on his foes. In one of the passages of the novel, Malinche prepares Cortés for war by telling him that to face a godworshipping empire, he would have to behave in a way that made him look like an invincible god in the eyes of the Aztecs. This passage offers a double reading. On the one hand, there is a strategic PR focus on articulating a message of success to the conquistador. On the other hand, the message conveys the power Malinche wields over him by virtue of her knowledge of the local contexts.

In essence, Una cruz de jade para Cortés is an alternative history - a history of resistance to the Aztec tyranny, in which the novelist presents the figure of a Spanish conqueror who makes strategic use of the knowledge and public relations skills of a Mexican woman to confront Moctezuma's domination. Cortés succeeds because, through Malinche, he is able to make common cause with the various indigenous tribes. The narrative provides an example of how the period of colonization had many complex layers. Although it involved conquests of lands and people, it also allowed the liberation of oppressed peoples in the 
colonized territories. It is, in its own way, a novel of resistance on behalf of indigenous men and women, and also of women in general. Communication is at the heart of such resistance.

\section{Re-reading the colonialist history of PR}

As historiographers of critical public relations are beginning to point out, the history of public relations does not begin with the formal practice and profession of PR. Rather, a "broader conception stretches through human history to include a range of public communication by regal, political, and religious leaders employing a variety of techniques" (LÉtang, 2016, p. 29). To broaden this conception further, we look at the deployment of, as well as a critique of, public relations by dominant coalitions in colonial times through the eyes of fictional characters in contemporary novels. The ideological obsession of PR with being part of a "dominant coalition” (Broom \& Dozier, 1985; Grunig \& Hunt, 1984; Grunig, 1992) has "aligned public relations with elite publics, often to supress those that stand up to corporate logic" (Munshi \& Kurian, 2016, p. 406; see also, Dutta-Bergman, 2005; Munshi \& Kurian, 2005). Colonial histories through contemporary novels reveal not just the ways in which dominant coalitions exercised power through communication interventions but also how this power was communicatively resisted by non-elites.

The works of Ghosh and Adichie bring to life the extraordinary reach of colonialist discourses in constructing particular, fragile identities of postcolonial nation states that have at their heart violence and coercion that mark their quest for survival. National identity for diverse postcolonial peoples remains an artificial construct created by trampling on other forms of community; and it is works such as these that delve into forgotten pasts, excavating voices, perspectives, and dreams that offer alternative readings of the project of modernity that colonialism imposed on Nigeria and India. In the same way, Perez-Regueira's (2014) work brings to light the power struggles that pre-date the Spanish conquest of Central 
America, and demonstrates how resistances and alliances, created and mediated by strategically placed women translators, played out in ways unacknowledged in current understandings of that region's history. These voices from the margins of history are a reminder of alternative ways of thinking and being that continue to have resonance today.

\section{References}

Alvesson, M., \& Ashcraft, K.L. (2011). Critical methodology in management and organization research. In D. Buchanan \& A. Bryman (Eds.), The Sage handbook of organizational research methods (pp. 61-77). London: Sage.

Amin, S. (1995). Event, metaphor, memory: Chauri Chaura 1922-1992. Delhi, India: Oxford University Press.

Bandyopadhyay, S. (1990). Caste, politics and the Raj: Bengal 1872-1937, Calcutta, India: K.P Bagchi.

Baudot, G. (2001). Malintzin, imagen y discurso de una mujer en el primer México virreinal. In M. Glantz (ed.), La Malinche, sus padres y sus hijos (pp. 60-84). México: Taurus.

Bourdieu, P. (2002). La domination masculine. Paris: Seuil.

Broom, G., \& Dozier, D. (1996). Using research in public relations: Applications to program management. Upper Saddle River, NJ : Prentice Hall.

Brotherson, G. (2001). La Malintzin de los códices. In M. Glantz (ed.), La Malinche, sus padres y sus hijos (pp. 3-27). México: Taurus.

Cao, Q. (2007). Western representations of the Other. In Shi-xu (Ed.), Discourse as cultural struggle (pp. 105-122). Hong Kong: Hong Kong University Press.

Adichie, C. (2004). Purple hibiscus. Lagos: Farafina.

Adichie, C. (2006). Half of a yellow sun. Lagos: Farafina. 
Adichie, C. (2009). The danger of a single story. TED Global talk:

http://www.ted.com/talks/chimamanda_adichie_the_danger_of_a_single_story.ht $\underline{\mathrm{ml}}$

Bennassar, B. (2001). Cortés: Le conquérant de l’impossible. Paris: Payot.

Candelaria, C. (1980). La Malinche, Femenist prototype. Frontiers 5(2), 1-6.

Chakrabarty, D. (2000). Provincializing Europe: Postcolonial thought and historical difference. Princeton, NJ: Princeton University Press.

Crhová, J. Escandón, A. (2011). Conceptualizing Malinche in discourse: An analysis from a sociocultural perspective. In A. Alson (Ed.), The evil body (pp. 184-192). Oxfordshire: Inter-Disciplinary Press.

Curzon, G.N. (1905). Lord Curzon in India; being a selection from his speeches as viceroy and governor-general of India 1898-1905. London: Macmillan.

Czarniawska, B. (2004). Narratives in social science research. London: Sage.

De Groot, J. (2016). Remaking History: The past in contemporary historical fictions. Abingdon, Oxford, UK: Routledge.

Diaz del Castillo, B. (1956). Historia verdadera de la conquista de la Nueva Espaha (The Discovery and Conquest of Mexico). New York, NY: Farrar, Straus, and Cudahy.

Doran, R. (2013). The work of Hayden White I: Mimesis, figuration and the writing of history. In N. Partner \& S. Foot (Eds.), The Sage handbook of historical theory (pp. 106-118). London: Sage.

Dutta, M. J., \& Pal, M. (2011). Public relations and marginalization in a global context: A postcolonial critique. In N. Bardhan \& K. Weaver (Eds.), Public relations in global cultural contexts. NY: Routledge.

Duverger, C. (2013). Henán Cortés: Más allá de la leyenda. Madrid: Taurus. 
Ekwe Ekwe, H. (2013). http://re-thinkingafrica.blogspot.co.nz/2013/07/britain-aburi-andigbo-genocide_14.html

Ekwe Ekwe, H. (2014). http://africandemocrat.com/content/britain-and-igbo-genocide\%E2\%80\%93-now-pertinent-questions-professor-herbert-ekwe-ekwe

Fehrenbach, T. R. (1973). Fire and blood: A history of Mexico. New York, NY: Macmillan. Fenton, C. and Langley, A. (2011), 'Strategy as practice and the narrative turn', Organization Studies 32(9): 1171-1196.

Ghosh, A. (2008). Sea of poppies. New York, NY: Farrar, Straus \& Giroux.

Ghosh, A. (2011). River of smoke. London: John Murray.

Ghosh, A. (2015). Flood of fire. New York, NY: Farrar, Straus \& Giroux.

Ghosh, A. \& Chakrabarty, D. (2002) ‘A correspondence on provincializing Europe,' Radical History Review 83: 146-172.

Grunig, J. (Ed.) (1992). Excellence in public relations and communication management. Hillsdale, NJ: Lawrence Erlbaum.

Grunig, J. \& Hunt, T. (1984). Managing public relations. New York: Holt, Rinehart and Winston.

Heath, R.L., \& Xifra, J. (2016). What is critical about critical public relations theory? In L’Etang, J., McKie, D., Snow, N., \& Xifra, J. (Eds.), Handbook of critical public relations (pp. 200-210). New York, NY: Routledge.

Hiebert, R. E. (2003). Public relations and propaganda in framing the Iraq war: a preliminary review. Public Relations Review 29 (3), 243-255

Hobson, K. (2010) 'The Indian caste system and the British: Ethnographic mapping and the construction of the British census in India', http://www.britishempire.co.uk/article/castesystem.htm 
Kellner, D. (2003). Bushspeak and the politics of lying: Presidential rhetoric in the "War on Terror”. Presidential Studies Quarterly 37 (4), 622-645.

Keulen, S. and Kroeze, R. (2012), Understanding management gurus and historical narratives: The benefits of a historic turn in management and organization studies. Management \& Organizational History 7(2): 171-189.

Lamme, M. O., \& Russell, K. M. (2010). Removing the spin: toward a new theory of public relations history. Journalism and Communication Monographs, 11(4), 281-362.

L’Etang, J., McKie, D., Snow, N., \& Xifra, J. (Eds.) (2016). The Routledge handbook of critical public relations. New York, NY: Routledge.

Martínez-San Miguel, Y. (2008). ¿Hacia unos estudios coloniales globales? : Entrecruces, aportes, limitaciones. In L. Melgar-Palacios (ed.), Persistencia y cambio: Acercamientos a la historia de las mujeres en México (pp. 64-77). Mexico: El Colegio de México.

McClintock, A. (1995). Imperial leather: Race, gender and sexuality in the colonial context. London: Routledge.

McKie, D., \& Xifra, J. (2016). 'Expanding critical space: Public intellectuals, public relations, and an "outsider" contribution,' in L'Etang, J., McKie, D., Snow, N., \& Xifra, J. (Eds.), Handbook of critical public relations (pp. 349-359). New York, NY: Routledge.

Meza, O. (1985). Malinalli Tenepal: La gran calumniada. Mexico: Edamex.

Miralles, J. (2001). Hernán Cortés, inventor de México. Mexico: Ediciones Folio.

Munshi, D., \& Kurian, P. (2005). Imperializing spin cycles: A postcolonial look at public relations, greenwashing, and the separation of publics. Public Relations Review 31(4), 513-520. 
Munshi, D., \& Kurian, P. (2007). The case of the subaltern public: A postcolonial investigation of CSR's (o)missions. In S. May, G. Cheney, \& J. Roper (Eds.), The debate over corporate social responsibility, New York, NY: Oxford University Press. (pp. 438-447).

Munshi, D., \& Kurian, P. (2016). 'Public relations and sustainable citizenship,' in L'Etang, J., McKie, D., Snow, N., \& Xifra, J. (Eds.), Handbook of critical public relations (pp. 405-414). New York, NY: Routledge.

Paz, O. (1993). El laberinto de la soledad (2 $2^{\text {nd }}$ ed.) Mexico: Fondo de Cultura Económica

Pérez-Regueira, J. L. (2014). Una cruz de jade para Cortés. Madrid: Éride.

Prakash, G. (1994). Subaltern studies as postcolonial criticism, The American Historical Review 99 (5), 1475-1490.

Prasad, A., Prasad, P., Mills, A.J., \& Mills, J.H. (2016). Debating knowledge: Rethinking critical management studies in a changing world. In A. Prasad, P. Prasad, A.J. Mills, \& J.H. Mills (Eds.), The Routledge companion to critical management studies (pp. 341). Abingdon, UK: Routledge.

Pratt, M. L. (1993)."Yo Soy La Malinche": Chicana writers and the poetics of ethnonationalism. Callaloo 16(4), 859-873.

Rhodes, C., \& Pullen, A. (2011). Narrative and stories in organizational research: An exploration of gendered politics in research methodology. In D. Buchanan \& A. Bryman (Eds.), The Sage handbook of organizational research Methods (pp. 583601). London: Sage.

Rowlinson, M. and Clark, P. (2004), 'The treatment of history in organisation studies: towards an "historic turn"?', Business History 46(3): 331-352. 
Russell, K. M., \& Lamme, M.O. (2016). Theorizing public relations history: The roles of strategic intent and human agency. Public Relations Review, doi:

http://dx.doi.org/10.1016/j.pubrev.2016.04.002

Said, E. (1978). Orientalism. New York, NY: Vintage Books.

Sanchez-Pinol, A. (2014). Victus: The fall of Barcelona. New York, NY: Harper Collins.

Sriramesh, K. (2009). The relationships between culture and public relations. In K. Sriramesh \& D. Vercic (Eds.), The global public relations handbook: Theory, research, and practice (pp. 47-61). New York, NY: Routledge.

Watson, T. (Ed.) (2015). Perspectives on public relations historiography and historical theorization: Other voices. Basingstoke, Hampshire, UK: Palgrave Macmillan.

White, H. (1973). Metahistory: The historical imagination in nineteenth century-Europe. Baltimore, MD: Johns Hopkins University Press.

\section{Funding}

No specific funding was received for this project. 